\title{
Multiple stressor effects on water quality in Poplar Bay, Lake of the Woods, Canada: a midge-based assessment of hypolimnetic oxygen conditions over the last two centuries
}

\author{
Jamie C. SUMMERS, Kathleen M. RÜHLAND, Joshua KUREK, Roberto QUINLAN, ${ }^{1}$ Andrew M. PATERSON ${ }^{2}$ \\ and John P. SMOL ${ }^{*}$ \\ Paleoecological Environmental Assessment and Research Laboratory (PEARL), Department of Biology, Queen's University, \\ Kingston, Ontario, K7L 3N6, Canada; ${ }^{1}$ Department of Biology, York University, Toronto, Ontario, M3J 1P3, Canada; ${ }^{2}$ Ontario \\ Ministry of the Environment, Dorset Environmental Science Centre, 1026 Bellwood Acres Road, Dorset, Ontario, P0A 1E0 \\ *Corresponding author: smolj@queensu.ca
}

\begin{abstract}
Chironomid and Chaoborus (midge) remains preserved in a dated sediment core from Poplar Bay, Lake of the Woods (LOW), Ontario, Canada, were used to assess the effects of multiple stressors (e.g., recent warming and shoreline development) on water quality over the past 200 years. As monitoring data for $L O W$ do not extend beyond recent decades, paleolimnological methods are used to reconstruct long-term limnological trends and to establish pre-disturbance conditions. The effects of recent warming and shoreline development on Poplar Bay water quality are examined using an index of hypolimnetic oxygen $\left(\mathrm{O}_{2}\right)$ status based on the ratio of Chaoborus to chironomid remains (chaob:chir) and a midge-inferred volume-weighted hypolimnetic oxygen (VWHO) model. Our paleolimnological data indicate that hypolimnetic $\left[\mathrm{O}_{2}\right]$ in Poplar Bay have been historically hypoxic (1-4 $\mathrm{mg} \mathrm{O}_{2} \mathrm{~L}^{-1}$ ) but have declined further (generally $<2 \mathrm{mg} \mathrm{O}_{2} \mathrm{~L}^{-1}$ ) over the last few decades. Significant relationships between air temperature and midge data indicate that substantial warming starting in the late-1970s has triggered a marked response in the midge assemblages that pre-dates the onset of cottage development (mid-1990s). These findings complement a diatom-based study on the same sediment core, likewise suggesting that recent warming has played a prominent role in structuring limnetic communities. However, it is likely that the full, compounded effects of recent warming and shoreline development have not yet been realized. Our study highlights the complexity of multiple stressor systems, such as Poplar Bay, and emphasizes the benefits of using multiple, independent lines of paleoenvironmental evidence in gaining a more complete understanding of historical water quality.
\end{abstract}

Key words: paleolimnology, multiple stressors, hypolimnetic oxygen, chironomid, Chaoborus, Lake of the Woods.

Received: August 2011. Accepted: October 2011.

\section{INTRODUCTION}

Lake of the Woods (LOW) is a hydrologically and morphologically complex freshwater system situated within the Canadian provinces of Ontario and Manitoba and the American state of Minnesota (Fig. 1). There is a strong gradient of lake water total phosphorus (TP) from north to south, with generally higher TP concentrations in the south and the lowest concentrations in the more isolated northern bays (DeSellas et al. 2009; Pla et al. 2005). Although historical records from explorers and missionaries describe the occurrence of cyanobacterial blooms dating back to the early $19^{\text {th }}$ Century (McElroy, and Riggs 1943; Robertson, and McCracken 2003), there is concern amongst current lake residents that water quality may be deteriorating (DeSellas et al. 2009). Recently, there have been reports that nuisance blooms have increased in intensity, frequency, and duration, particularly in the northern regions of LOW (DeSellas et al. 2009). Due to a lack of continuous, long-term monitoring data for many re- gions of LOW, the nature and magnitude of recent changes are difficult to establish (Pla et al. 2005). Additionally, anthropogenic disturbances acting on LOW (e.g., European settlement, hydromanagement activities, residential development) often pre-date the initiation of limnological monitoring programs. Consequently, estimates of pre-disturbance or baseline environmental conditions, critical for providing a context for realistic mitigation targets, are required for freshwater lakes impacted by multiple stressors (Hall, and Smol 2010; Quinlan et al. 2008).

Similar to lakes throughout Ontario, there are numerous stressors acting on LOW and it can be very challenging to interpret the cumulative effects that these stressors exert on aquatic systems (Keller 2009; Quinlan et al. 2008; Smol 2010). This is especially true given the paucity of long-term, continuous monitoring data for LOW. The compounding effects of increases in regional air temperatures, longer ice-free periods, longer periods of thermal stratification, and intensified shoreline development are some examples of the multiple stressors that 


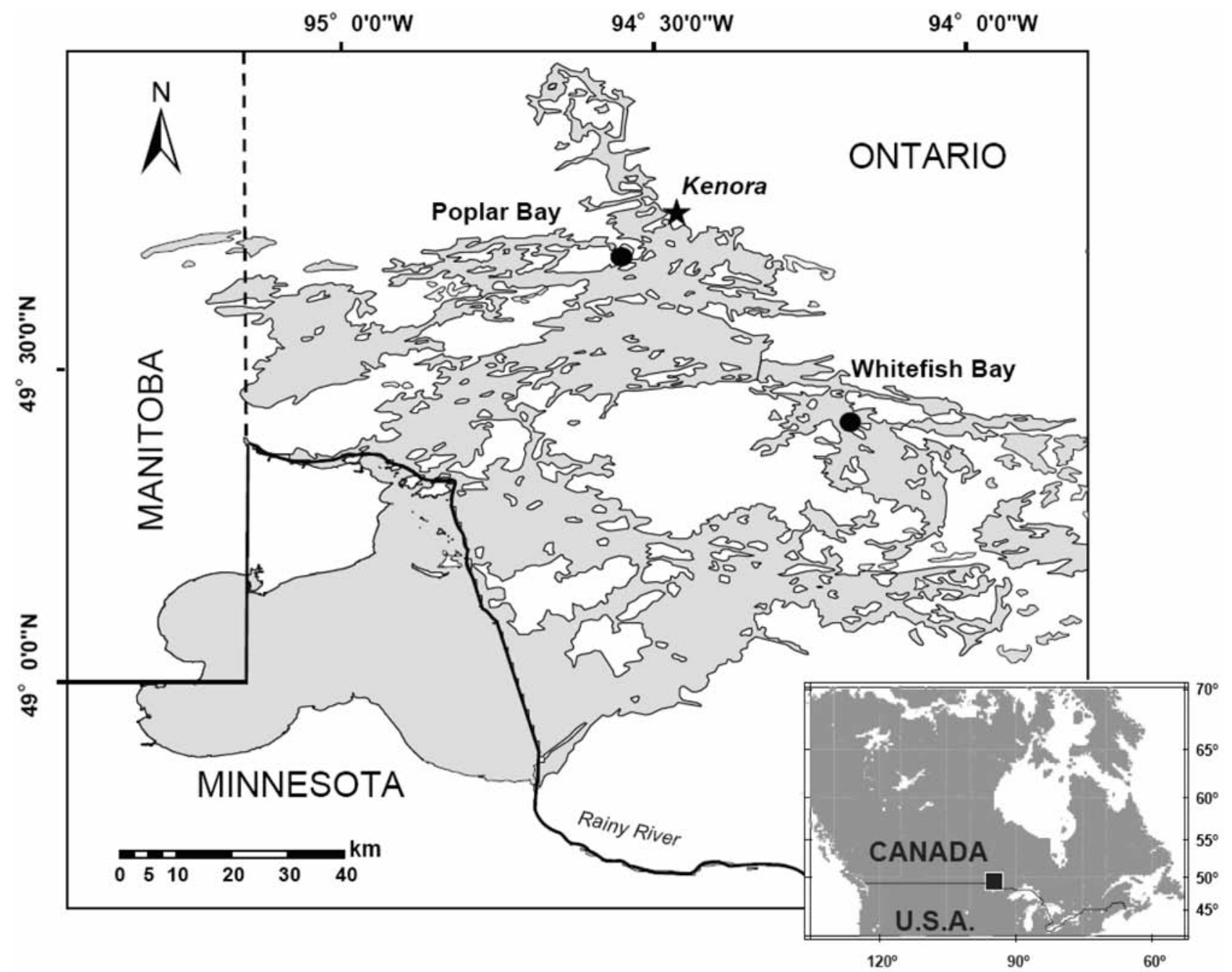

Fig. 1. Map showing the location of the study region, Lake of the Woods, Ontario. Black circles represent Poplar Bay and Whitefish Bay (reference site for ice-out data). The star denotes the city of Kenora.

have been associated with increases in cyano-bacterial blooms (Paerl, and Huisman 2008; Rühland et al. 2010; Smol 2010). It is expected that the individual effects of these stressors could result in the depletion of hypolimnetic $\left[\mathrm{O}_{2}\right]$ and diminishing water quality (Brodersen, and Quinlan 2006), but cumulative impacts may differ from individual effects (Christensen et al. 2006). By providing a long-term perspective on water quality changes using a multiple-proxy approach, paleolimnology can provide important insights into the cumulative impacts of multiple stressors (Quinlan et al. 2008; Smol 2008).

In 2010, a diatom-based paleolimnological study was conducted on the same sediment core analyzed here from Poplar Bay. Hyatt (2010) used a diatom inference model to assess [TP] and ecological changes in the bay in response to a multitude of environmental stressors. Our study builds on the findings of Hyatt (2010) by examining long-term changes in hypolimnetic $\left[\mathrm{O}_{2}\right]$, an important en- vironmental indicator in aquatic ecosystems. Hypolimnetic $\left[\mathrm{O}_{2}\right]$ can be influenced by interactions among stressors, including climate-induced changes in thermal stability, inputs from the catchment, and eutrophication (Brodersen, and Quinlan 2006). Changes over time can be tracked using the changes in community structure (Aagaard 1986) and abundances (Kajak 1997) of the remains of non-biting midges (i.e., Chironomidae and Chaoborus) preserved in lake sediments (Brodersen, and Quinlan 2006). For example, some chironomids use increased levels of hemoglobin (Czeczuga 1960; Weber 1980), migration strategies (Bazzanti et al. 1998), or tube ventilation (Brodersen, and Quinlan 2006) to tolerate low $\left[\mathrm{O}_{2}\right]$, whereas Chaoborus typically use high levels of hemolymph (Scholz, and Zerbst-Boroffka 1998; Jäger, and Walz 2002), and some taxa are able to migrate through the water column (Wissel et al. 2003; Sweetman, and Smol 2006). Due to the distributions and abundances of 
midge taxa reflecting a range of $\left[\mathrm{O}_{2}\right]$ optima and tolerances, assemblage changes are often used as indicators of $\left[\mathrm{O}_{2}\right]$ and water quality (Brodersen, and Lindegaard 1999; Brooks et al. 2001; Quinlan, and Smol 2001a; Luoto, and Salonen 2010). In addition, primary production and respiration rates typically affect the availability of $\left[\mathrm{O}_{2}\right]$ in the hypolimnion; therefore, assemblages of midges can also be used as an indirect indicator of epilimnetic water quality changes in stratified lakes (Brodersen, and Quinlan 2006).

In this study, we use midge-based paleolimnological techniques to establish baseline conditions and to examine historical trends in water quality and hypolimnetic $\left[\mathrm{O}_{2}\right]$ over the last 200 years in Poplar Bay, LOW. We investigate midge assemblage changes in the context of lake-level management impacts at the turn of the $20^{\text {th }}$ Century and recent environmental stressors (e.g., warmer air temperatures since the $\sim$ late-1970s, and substantial shoreline development since the $\sim$ mid-1990s). Additionally, we explore the effectiveness of a recently developed paleolimnological index for hypolimnetic oxygen concentration (i.e., chaob:chir index), and compare these trends with a quantitative midge-inferred model used to reconstruct volumeweighted hypolimnetic oxygen (VWHO) (Quinlan, and Smol 2010). We then compare our midge-based findings with diatom trends from the same sedimentary core, including a diatom-inferred total phosphorus (DI-TP) model (Hyatt 2010). Collectively, these multiple-proxy data are used to assess the impacts of multiple environmental stressors on the overall water quality of Poplar Bay.

Study area - Lake of the Woods

LOW $\left(49^{\circ} 18^{\prime} \mathrm{N}, 94^{\circ} 36^{\prime} \mathrm{W}\right)$ is a complex freshwater system consisting of numerous distinct depositional basins within an extensive international watershed (Fig. 1). Approximately $70 \%$ of the inflow to LOW, as well as the main source of total phosphorus, comes from the Rainy River to the south (DeSellas et al. 2009; Hargan et al., in press), which then flows northward through the main channel. The primary outlet empties into the Winnipeg River at the far north of the lake (Yang, and Teller 2005). LOW has a large surface area $\left(4427 \mathrm{~km}^{2}\right)$ with a varied morphology, particularly in the north, where it is characterized by thousands of islands, inlets, and bays (Yang, and Teller 2005). Boreal forest (International Joint Commission 1984) and Precambrian Shield bedrock (Ontario Geological Survey 2010) dominate the northern regions of the lake and its catchment. Wetlands and glacial sediment from Lake Agassiz are predominantly present in the south (DeSellas et al. 2009; Yang, and Teller 2005).

LOW has been subjected to numerous anthropogenic disturbances beginning in the mid to late- $19^{\text {th }}$ Century, including land clearance for settlement, establishment of logging sawmill operations, and the construction of sev- eral dams for water-level control and hydroelectric power generation (Serieyssol et al. 2009; Rühland et al. 2010; Yang, and Teller 2005). Most notably, the construction of hydroelectrical dams, powerhouses, and subsequent modifications to the two primary outflows to increase overflow capacity between $\sim 1887$ and $\sim 1925$, resulted in an average lake-wide increase in water level of $\sim 1.8 \mathrm{~m}$ (Yang, and Teller 2005). The dams currently maintain stable water levels throughout LOW and result in a uniform flow (LOWCB 2002).

Air temperature data from the Kenora Airport Climate Station ( $\sim 10 \mathrm{~km}$ from Poplar Bay) show that LOW is in a region that has undergone substantial increases in mean annual temperature $\left(\sim 1.2^{\circ} \mathrm{C}\right)$ over the last $\sim 100$ years with the most pronounced increases recorded in the winter months $\left(\sim 2.3^{\circ} \mathrm{C}\right)$ (Rühland et al. 2008, 2010). Substantially warmer air temperatures have resulted in an increase in the ice-free period on Whitefish Bay, a minimally impacted bay on LOW, by $\sim 28$ days since the mid-1960s, thus affecting the onset, duration, and strength of thermal stratification (Rühland et al. 2008, 2010).

Study area - Poplar Bay

Poplar Bay $\left(49^{\circ} 69^{\prime} \mathrm{N}, 94^{\circ} 56^{\prime} \mathrm{W}\right)$ is a moderately deep $\left(Z_{\max }=29 \mathrm{~m}\right)$, isolated bay in the northern portion of LOW in Ontario (Fig. 1). It is currently slightly mesotrophic (average spring [TP] of surface water in 2008 was $\sim 11.0 \mu \mathrm{g}$ $\mathrm{L}^{-1}$ ) (Hargan 2010). The bay thermally stratifies at the end of the summer period and drains toward the main channel (Hyatt 2010). Measured oxygen-temperature profiles (unpublished data T. Mosindy, MNR Kenora) indicate that the site stratifies at 7-8 $\mathrm{m}$ depth, and the hypolimnion can be anoxic $\left(<1 \mathrm{mg} \mathrm{O}_{2} \mathrm{~L}^{-1}\right)$ by the end of summer. In the mid-1990s, Poplar Bay experienced a rapid increase in shoreline development with the construction of $\sim 150$ seasonal cottages (Hargan 2010). The cumulative impact of development for Poplar Bay is determined relative to other bays on LOW and considers the year of first development, the duration and type of development, the number of residences on the shoreline, and the percentage of total TP load that is attributed to septic tanks (Hargan 2010). On Poplar Bay, the degree of development and estimated nutrient contributions from the shoreline development are of comparatively high magnitudes; therefore, Poplar Bay is classified as an area under high shoreline development pressure (Hyatt 2010). Similar to many regions of LOW, the water quality in Poplar Bay has become a recent point of concern for lake residents, partly due to perceived increases in cyanobacterial blooms. Currently, the long-term effects on water quality as a result of rapid shoreline development on Poplar Bay are poorly understood and are complicated by the uncertainties surrounding the impacts of multiple stressors, not least of which is recent warming. 


\section{MATERIALS AND METHODS}

Sample collection

In August 2008, duplicate sediment cores, core A (39.5 $\mathrm{cm})$ and core B $(30.0 \mathrm{~cm})$ taken several metres apart, were collected from a depth of $26.0 \mathrm{~m}$ near the centre of the Poplar Bay basin. Cores were collected using a gravity corer (Glew 1989). On shore, cores were sectioned into $0.5 \mathrm{~cm}$ intervals using a vertical extruder (Glew 1988). Sediments were stored at $4^{\circ} \mathrm{C}$ in Whirlpak ${ }^{\circledR}$ bags until they were processed at Queen's University Paleoecological Environmental Assessment and Research Laboratory (PEARL). Core A was the primary core used in this study. The top $0.5 \mathrm{~cm}$ interval of core B was used to provide supplementary sediment for the watery core A surface interval.

Radiometric dating of the Poplar Bay sediment core was undertaken by Hyatt (2010) using gamma spectrometry. Briefly, the chronology of the core was calculated from ${ }^{210} \mathrm{~Pb}$ activities and cumulative dry mass using the constant rate of supply (CRS) model (Appleby 2001) to estimate dates for the past $\sim 130$ years. Additionally, ${ }^{137} \mathrm{Cs}$ was used as an independent chronological marker of the radioactive fallout resulting from the 1963 treaty banning nuclear weapon testing and was used to corroborate the ${ }^{210} \mathrm{~Pb}$ dates (Appleby 2001).

Midge assemblage processing and identifications

Sediments were processed for midge analyses following the standard procedures for subfossil midges given in Walker (2001). Between $\sim 0.2$ and $3.2 \mathrm{~g}$ of dry sediment (or the wet sediment equivalent) from each interval was treated with $5 \%$ potassium hydroxide $(\mathrm{KOH})$ and warmed using a hot plate for $\sim 30$ minutes. Samples were then rinsed with deionized water and sieved using a $95-\mu \mathrm{m}$ mesh sieve. Midge remains were then washed from the surface of the sieve into a beaker and aliquots were poured into a Bogorov counting tray. Making four passes through each tray, chironomid head capsules and Chaoborus mandibles were handpicked using fine forceps under a dissecting microscope at $\sim 20 \times$ magnification. All samples were processed and picked entirely to avoid a non-random sorting bias within the beaker and tray. The remains were then transferred to a cover slip and mounted permanently using Entellan ${ }^{\circledR}$. A minimum of 50 individuals was the targeted count for each interval (Quinlan, and Smol 2001b).

Midge remains were identified every $0.5 \mathrm{~cm}$ for the top $2.0 \mathrm{~cm}, 1.0 \mathrm{~cm}$ for intervals from 2.0 to $16.0 \mathrm{~cm}$, and every 2.0 to $4.0 \mathrm{~cm}$ for the remainder of the core. With particular interest in sediments from the most recent century, more sediment intervals were counted in the younger sections of the core compared to the older sections. As a result, interpretations regarding changes prior to $\sim 1900$ (pre-disturbance) were made with caution. Taxa were identified using bright-field optics at 400× magnification. Chironomid head capsules and Chaoborus mandibles were identified to the lowest reasonable taxonomic level using Brooks et al. (2007), Wiederholm (1983), and Uutala (1990). Midge taxa were expressed as percent relative abundances of the total number of midges counted in each sample (i.e., two Chaoborus mandibles or 2 chironomid mentum halves were equal to one individual).

\section{Downcore numerical analysis}

Midge relative abundances were stratigraphically displayed and biostratigraphical zones were established through cluster analysis using constrained incremental sum of squares (CONISS) available with TGView v. 2.0.2 (Grimm 2004). For clarity in data display, taxa that did not exceed $\geq 4 \%$ relative abundance in at least 2 sediment intervals were not included in the stratigraphy, but were included in all statistical analyses. The major patterns of variation in the midge stratigraphical sequence were summarized using principal components analysis (PCA: covariance matrix) in the computer program CANOCO for Windows, version 4.5 (ter Braak, and Šmilauer 2002). Midge data were squareroot transformed prior to analysis to equalize the variance among taxa. PCA axis 1 and axis 2 sample scores enabled comparisons of midge assemblage trends to observed climate records available from the Kenora Climate Station, Ontario (Historical Adjusted Climate Database for Canada, Environment Canada: http://www.ccma.ec. gc.ca/hccd/).

An index comparing the Chaoborus mandible abundance relative to the chironomid head capsule abundance, chaob:chir, was used to qualitatively infer the changes in hypolimnetic $\left[\mathrm{O}_{2}\right]$ (Quinlan, and Smol 2010). Additionally, a VWHO model that included Chaoborus and chironomids was also used to infer quantitative changes in hypolimnetic $\left[\mathrm{O}_{2}\right]$ at Poplar Bay. The inclusion of Chaoborus was warranted as the taxon improves the accuracy of the quantitative inferences from VWHO models when applied to deep $\left(Z_{\min }=10.7 \mathrm{~m}\right)$, thermally stratified lakes with low $\left[\mathrm{O}_{2}\right]$ (Quinlan, and Smol 2010), similar to the physical and chemical attributes of Poplar Bay, LOW.

The VWHO inference model applied was a weightedaveraging (WA) model with tolerance down-weighting and inverse deshrinking, comprised of 45 midge taxa, including Chaoborus, from 54 stratified south-central Ontario lakes, with a crossvalidated model error of $1.98 \mathrm{mg}$ $\mathrm{O}_{2} \mathrm{~L}^{-1}$ and a jackknifed coefficient of determination $\left(r^{2}\right)$ of 0.60 (Quinlan, and Smol 2010). The taxonomy of the LOW dataset was harmonized with that of the VWHO inference model, which included changes such as merging Chironomus plumosus-type and C. anthracinus-type, merging several Tanytarsini taxa (such as Tanytarsus mendax-type and T. pallidicornis-type) into Tanytarsus s.lat., 


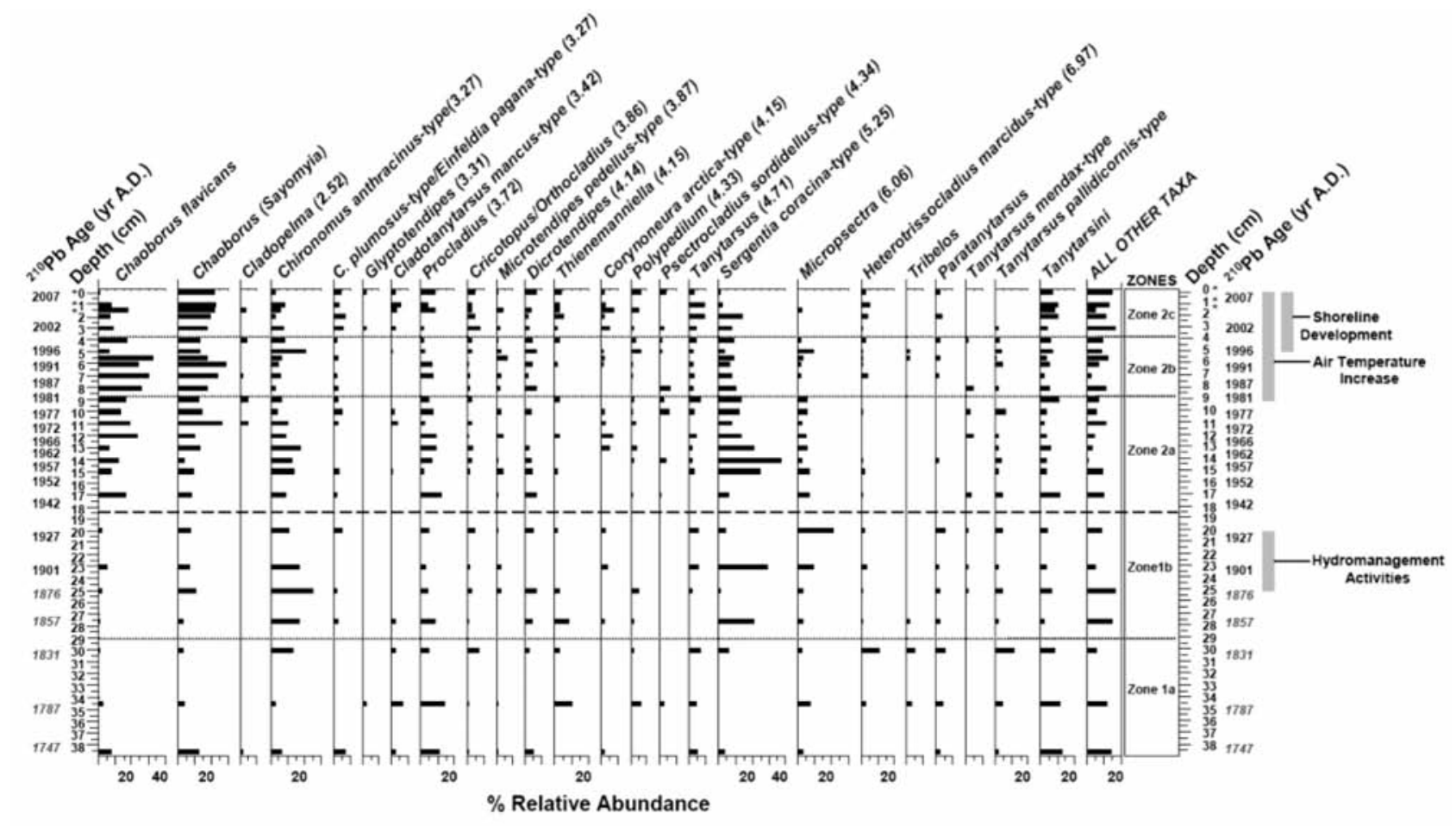

Fig. 2. Percent relative abundances of common midge taxa. Taxa are sorted according to their optima for $\left[\mathrm{O}_{2}\right]$ from lowest to highest (based on Quinlan and Smol, 2001a), which are indicated in parentheses following taxon names. Taxa optima are not indicated when the information is unknown. Biostratigraphical zones are represented by dashed horizontal lines. Asterisks $(*)$ indicate intervals with low midge counts. ${ }^{210} \mathrm{~Pb}$ dates that were extrapolated beyond the background activities are italicized.

and merg-ing Corynoneura and Thienemanniella. The inference model and reconstruction were generated using the software program C2 v1.5 (Juggins 2007).

To investigate relationships between midge trends from Poplar Bay and observed air temperatures, comparisons were made between the chaob:chir index with temperature records from the nearby Kenora climate station. The temperature data from the Kenora climate station is highly representative of temperature trends in the region as there is a strong correlation among temperature data from numerous climate stations in the area (Rühland et al. 2010). We use the Kenora temperature data because it is the closest climate station to Poplar Bay and has the longest continuous record of temperature data in the area. Although mean annual, winter, and spring temperature data from Kenora all showed strong relationships with the Poplar Bay midge trends, we display only the correlation with average spring temperature because of its particularly striking relationship with the midge trends. To ensure that comparisons between the chaob:chir index and the temperature data were made at a similar temporal resolution, we applied a smoother to the temperature record. A 7-year running average was chosen based on the largest number of years represented by a given sedimentary interval in the Poplar Bay core.

\section{RESULTS}

Midge assemblage trends from Poplar Bay

A total of 53 taxa were identified from the Poplar Bay core. Midge counts were relatively low throughout the core $(\min =37, \max =80$, median $=52)$ and the top $1.0 \mathrm{~cm}$ was particularly sparse in remains. The common midge taxa were plotted stratigraphically to show the timing and nature of midge community changes over the last $\sim 250$ years (Fig. 2). CONISS identified five main zones of distinct midge assemblage compositions. ${ }^{210} \mathrm{~Pb}$ activity profiles for Poplar Bay sediment core followed a characteristic exponential decline through depth (Hyatt 2010). Initial ${ }^{210} \mathrm{~Pb}$ activities were relatively high $(\sim 50$ $\left.\mathrm{dpm} \mathrm{g}^{-1}\right)$ and the dating errors were relatively low ( $\sim 1$ to 3 years for the top $10 \mathrm{~cm}$ of the core and $\sim 6$ to 36 years from 15 to $25 \mathrm{~cm}$ depth).

In general, Chaoborus [C. flavicans and C. (Sayomyia)] were common throughout the core and reached high relative abundances, $>25 \%$, after the mid- $20^{\text {th }} \mathrm{Cen}$ tury (Fig. 2). Dominant chironomids included the profundal taxa Chironomus anthracinus-type and Sergentia coracina-type and, to some extent, Procladius and Tanytarsini were also common and abundant.

Zone 1a defines the baseline conditions for Poplar Bay 
a)

b)

c)

d)

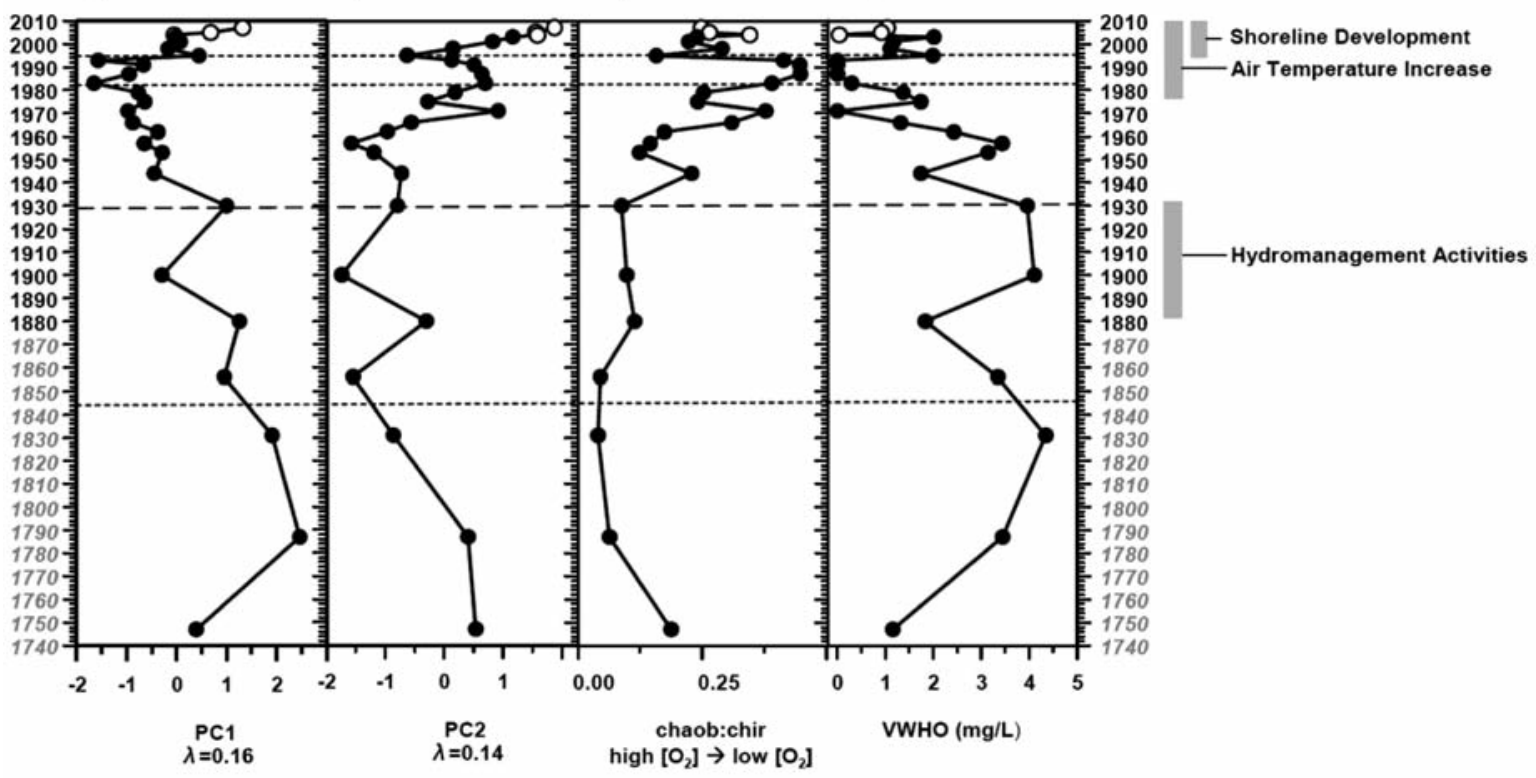

Fig. 3. Summary of paleolimnological trends including principal components analysis (PCA) sample scores for midges on axes 1 and 2 ( $a, b)$, a ratio comparing Chaoborus mandible abundance to chironomid head capsule abundance (chaob:chir) (c), and VWHO inferences from a Chaoborus and chironomid inclusive VWHO model with a root mean squared error of prediction of $\pm 1.98 \mathrm{mg} \mathrm{O}_{2} \mathrm{~L}^{-1}(\mathrm{~d})$. Dashed horizontal lines represent biostratigraphical zones. Grey italicized dates were extrapolated. Intervals with low midge counts are indicated with white circles.

and Zone $1 \mathrm{~b}$ reflects the initial period of hydro-management. In Zone 1a, from $\sim 1740$ until 1840, the midge assemblages were characterized by moderate abundances of Tanytarsini and Procladius. In Zone 1b, relative abundances of $C$. anthracinus-type and S. coracina-type increased until the mid-1930s, where a large relative increase in C. flavicans and C. (Sayomyia) began and represented the start of Zone 2a, the most substantial change in the assemblage. Additionally, there was a subtle decline in the relative abundances of $S$. coracina-type, a taxon with a moderately high $\left[\mathrm{O}_{2}\right]$ optimum. The late-1970s marked the beginning of Zone $2 \mathrm{~b}$ with a further increase in Chaoborus and a concurrent decline in C. anthracinustype and $S$. coracina-type. Zone $2 \mathrm{c}$ extended from the mid-1990s to the year of coring (2008). The relative abundance of $C$. (Sayomyia) remained high and C. flavicans declined.

Hypolimnetic $\left[\mathrm{O}_{2}\right]$ dynamics reflected by shifts in midge taxa were summarized and quantified through the chaob:chir index and VWHO model. Early in the record, chaob:chir was low and there was minimal change until the mid-1930s (Fig. 3c). PCA axis 1 and 2 also exhibited minimal change during this period and the VWHO model inferred moderate and relatively stable $\left[\mathrm{O}_{2}\right]$ levels prior to the mid-1900s (Figs 3a,b, and d). After the early-19 ${ }^{\text {th }}$ Century, the chaob:chir index increased and the VWHO model inferred a decline to extremely low hypolimnetic
$\left[\mathrm{O}_{2}\right]$ conditions. These trends persisted until the late-1970s when a substantial change in midge assemblage composition (PCA sample scores) was observed and a continued decline in midge-inferred hypolimnetic $\left[\mathrm{O}_{2}\right]$ was evident in the chaob:chir, and the VWHO model (Fig. 3). The mid-1990s marked the most recent shift evident in the midge assemblage. The trend showed a subtle decrease in the chaob:chir index and a similar increase in midge-inferred VWHO corresponding to changes in the overall midge assemblage composition. Although chaob:chir and the VWHO model inferred increases in hypolimnetic $\left[\mathrm{O}_{2}\right]$, the concentrations remained below pre-industrial values. High positive correlations $(r=0.62 ; p<0.004)$ were observed between the Kenora air temperature records and the chaob:chir index (Fig. 4). PCA axis 1 sample scores and the Kenora air temperature records also showed high positive correlations $(r=0.66 ; p<0.002)$ (data not shown).

\section{DISCUSSION}

Trends in midge-inferred hypolimnetic $\left[\mathrm{O}_{2}\right]$ and the chaob:chir index

The composition of the Poplar Bay midge assemblages have undergone notable change over the last $\sim 200$ years and VWHO inferences suggest that oxygen concentrations for Poplar Bay ranged between 1-4 mg O $\mathrm{O}_{2} \mathrm{~L}^{-1}$ prior to the turn of the $20^{\text {th }}$ Century, and has since de- 
clined. The naturally hypoxic hypolimnion in Poplar Bay is consistent with diatom-inferred nutrient levels (i.e., TP) from the same sediment core, indicating that Poplar Bay was naturally mesotrophic prior to significant anthropogenic disturbance in LOW (Hyatt 2010).

The trends in the midge assemblages, PCA sample scores, chaob:chir, and the midge-based VWHO inferences (Fig. 3) suggest that hydromanagement activities during the early $20^{\text {th }}$ Century resulted in the initial decline in hypolimnetic $\left[\mathrm{O}_{2}\right]$. This midge assemblage shift appears to occur later (mid-1930s) than one would expect if the change were due to the onset of hydromanagement activities (early-1900s). The apparent delay may be an artifact of the relatively coarse counting resolution in this section of the sedimentary profile (e.g., only one counted sedimentary interval representing $\sim 1900$ to $\sim 1935$ ).

Relationships between the youngest sedimentary midge assemblages in Poplar Bay, climate warming in the middle of the $20^{\text {th }}$ Century, and the surge in shoreline development in the mid-1990s indicate that climate warming and cottage construction are likely playing important roles in the current hypolimnetic $\left[\mathrm{O}_{2}\right]$ status of Poplar Bay. Our data show evidence that the Poplar Bay midge assemblage is responding strongly to warming temperatures over the last $\sim 100$ years, particularly to accelerated warming from the late-1970s onward. The mid-1990s midge assemblage change occurs during a period of shoreline development on Poplar Bay; however, contrary to the expected response to this additional stressor, inferred hypolimnetic $\left[\mathrm{O}_{2}\right]$ shows an increasing trend. This midge-inferred increase in hypolimnetic $\left[\mathrm{O}_{2}\right]$ is likely the result of disturbances in the nearshore environment leading to the development of new littoral habitats for chironomid taxa with higher oxygen optima. Hyatt (2010) also concluded, from a diatom study using the same sediment core, that recent climate warming played a dominant role in water quality in Poplar Bay. Based on a diatom-inferred TP model, recent shoreline development did not appear to be driving the diatom assemblage changes. Similar to our findings, the nature of the diatom assemblage changes suggest that the recent surge in cottage construction on Poplar Bay resulted in the establishment of new nearshore habitats for benthic diatom taxa (Hyatt, pers. comm.). Deciphering the specific impacts of the multiple stressors on water quality is challenging and not always possible. However, examining long-term trends in multiple environmental proxies will provide important insights into the recent impacts of multiple stressors on hypolimnetic $\left[\mathrm{O}_{2}\right]$ and the overall water quality of Poplar Bay, LOW.

From the midge-based paleolimnological record, hydromanagement practices, recent warming, and shoreline development are identified as three important influences on Poplar Bay's water quality over the last $\sim$ two centuries.
Although of a coarser counting resolution compared to the diatom data, the midge trends in the oldest sedimentary intervals of the Poplar Bay core correspond with the diatom trends indicating that the water quality in Poplar Bay was generally stable until the onset of hydromanagement activities at the turn of the $20^{\text {th }}$ Century (Figs $3 a$ and b). This first post-disturbance assemblage shift occurred in the early $20^{\text {th }}$ Century and is evident with an increase in the chaob:chir index and a decline in inferred hypolimnetic $\left[\mathrm{O}_{2}\right]$. It is difficult to more accurately pinpoint this change given the coarser counting resolution that we achieved in the older sedimentary intervals. For example, only one counted midge interval represents a time span of $\sim 1900$ to $\sim 1945$, with an estimated age for this interval of $\sim$ mid-1930s.

The construction of dams and the control of LOW outflow capacity between the late-1880s and the mid-1920s resulted in a $\sim 1.8 \mathrm{~m}$ rise in water level (Yang, and Teller 2005; DeSellas et al. 2009). The resulting changes in lake water properties, including increased water residence time, increased shoreline erosion, short-lived nutrient and turbidity increases, and modified water column mixing may have triggered a large-scale ecosystem turnover across the lake (Rühland et al. 2010). It is plausible that changes in Poplar Bay water properties initiated in the early 20th Century, may have generated a decline in hypolimnetic $\left[\mathrm{O}_{2}\right]$ that resulted in a shift to a midge community that is tolerant of lower $\left[\mathrm{O}_{2}\right]$ (e.g., increased abundances of Chaoborus and $\mathrm{O}_{2}$ depletion-tolerant species of chironomids such as $C$. anthracinus-type). The changes in the Poplar Bay midge assemblage are consistent with previous diatom-based paleolimnological studies that recognized the effects of hydromanagement activities on LOW and the surrounding region from $\sim$ late $19^{\text {th }} \mathrm{Cen}$ tury to $\sim$ early $20^{\text {th }}$ Century (Serieyssol et al. 2009; Rühland et al. 2010; Hyatt et al. 2011).

Recent multiple stressors in Poplar Bay: climate warming and shoreline development

One of the most notable changes in midge assemblage composition and a further decline in inferred hypolimnetic $\left[\mathrm{O}_{2}\right]$ (late-1970s to mid-1990s) occurs during a period of the highest air temperature increases in the region (Rühland et al. 2008, 2010). It is important to note that this assemblage shift occurs prior to the onset of shoreline development on Poplar Bay (mid-1990s). Given that the errors associated with ${ }^{210} \mathrm{~Pb}$ dates near the surface of the core are minimal ( \pm 1 to 2 years), greater confidence can be given to the timing of more recent changes depicted in the Poplar Bay sediment core. The chronological order of the shift is significant because the timing, combined with observations in the instrumental climate record, suggests that the commencement of the hypolimnetic $\left[\mathrm{O}_{2}\right]$ decline appears to correspond to regional climate warming, rather 


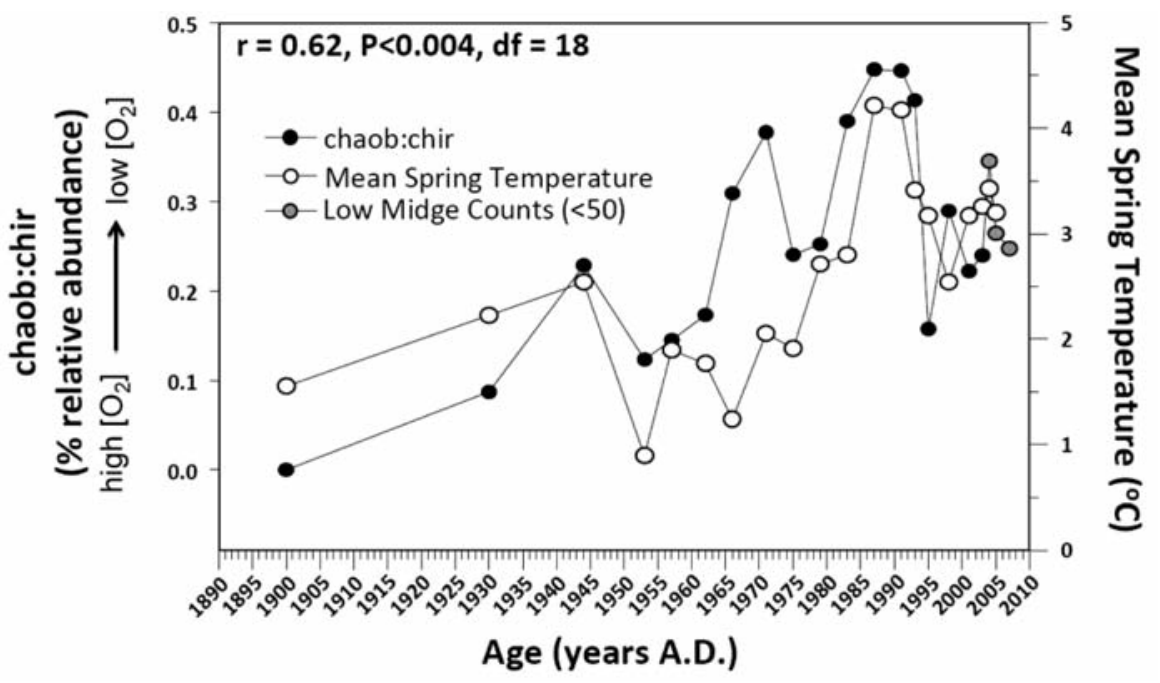

Fig. 4. Correlation of Kenora, Ontario, mean spring temperatures and an index of Chaoborus relative abundance compared to chironomid relative abundance. Temperature data is from the Historical Adjusted Climate Database for Canada, Environment Canada (http://www.cccma.ec.gc.ca/hccd/).

than shoreline development. Prior to the mid-1990s, inferred $\left[\mathrm{O}_{2}\right]$ had already declined to the lowest values of the $\sim 200$-year record.

Strong and significant correlations between the Poplar Bay midge data and the Kenora temperature record, particularly mean spring temperature trends, provide compelling evidence that substantial warming over the last few decades has played an increasingly important role in structuring the midge assemblage (Fig. 4). These relationships are consistent with conclusions reached from diatom trends from the same core (Hyatt 2010) and from diatom trends found throughout other bays of the LOW (Rühland et al. 2008; Hyatt et al. 2011). Much like the shifts in diatom communities, midge-inferred hypolimnetic $\left[\mathrm{O}_{2}\right]$ trends can be linked to warming-induced changes in lake water properties, including, for example, alterations in the strength and duration of thermal stratification from changes in the length of the ice-free season (Brodersen, and Quinlan 2006). The 28-day increase in the ice-free season on Whitefish Bay since the mid-1960s is a substantial change that is driven by recent increases in regional air temperature (Rühland et al. 2008, 2010). Changes in aquatic biota associated with the increased ice-free season provide strong evidence suggesting that regional climate warming is having an appreciable effect on water quality in LOW.

These warming-induced changes can differ in their impacts on nutrient cycling depending on lake thermal stratification regimes (Brodersen, and Quinlan 2006). Poplar Bay experiences strong thermal stratification and anoxia at the end of the summer period (unpublished data T. Mosindy, MNR Kenora). The increasing trend in regional air temperature has been linked to an increase in the ice-free season (i.e., growing season) and the duration and strength of thermal stratification in other bays on the LOW, particularly Whitefish Bay, and will favour the proliferation of cyanobacteria in other LOW sites with already elevated concentrations of nutrients (Rühland et al. 2010). An increase in respiration rates following bloom die-off can further promote hypoxic stress (Paerl, and Huisman 2008). The striking correlation between the chaob:chir index from Poplar Bay and mean spring air temperature provides strong evidence that climate plays an important role in the recent changes in hypolimnetic $\left[\mathrm{O}_{2}\right]$ conditions of Poplar Bay. Stratified lake systems, such as Poplar Bay, will experience increased hypoxic stresses from the effects of climate warming both due to increased biological oxygen demand from warmer temperatures (Blumberg, and Toro 1990) and changes in the duration, strength, and depth of thermal stratification (Jankowski et al. 2006).

The VWHO model that includes Chaoborus relative abundance data with chironomid data was used on Poplar Bay assemblages and was likely more realistic than a VWHO model that is based solely on chironomid data in quantifying VWHO levels in lakes with low $\left[\mathrm{O}_{2}\right]$ and the aforementioned physical properties (Quinlan, and Smol 2010). Several studies have shown that including other biological indicators, in addition to chironomids, can be beneficial in paleolimnological analyses because the entire profundal communities of chironomids can be extirpated under extreme anoxia (e.g., Clerk et al. 2000, 2004; Little et al. 2000; Reavie et al. 2006). Using only chironomid relative abundances can skew the relative ratio of littoral taxa compared to profundal taxa and can potentially underestimate the extent of low $\left[\mathrm{O}_{2}\right]$ conditions (Quinlan, 
and Smol 2010). Chaoborus have a stronger relationship with low $\left[\mathrm{O}_{2}\right]$ and generally better reflect hypoxic environments (Wissel et al. 2003) compared to some chironomid taxa that are tolerant of low $\left[\mathrm{O}_{2}\right]$. Thus, the combined use of chironomids and Chaoborus appears to more accurately reflect the continuous gradient of $\left[\mathrm{O}_{2}\right]$ in hypoxic or anoxic environments (Quinlan, and Smol 2010). However, the maximum (53\%) and mean (26\%) relative abundance of Chaoborus in the LOW sediment record exceed those values within the applied training set (Quinlan, and Smol 2010). As a result, the VWHO inferences may be lower than the "true" hypolimnetic $\left[\mathrm{O}_{2}\right]$, and our quantitative reconstruction may underestimate the total magnitude of change; therefore, we focused on the pattern of change and not the absolute VWHO values.

The most recent shift in midge assemblage composition (mid-1990s to present) in Poplar Bay qualitatively suggests a minor improvement in hypolimnetic $\left[\mathrm{O}_{2}\right]$ conditions, although measures remain well below pre-disturbance conditions. Given that this time period coincides with the onset of rapid cottage development on Poplar Bay, it is unlikely that this subtle increase in hypolimnetic $\left[\mathrm{O}_{2}\right]$ is an indication of an overall improvement in water quality. Rather, there are several possibilities that may explain this unexpected trend highlighted by the chaob:chir index. Firstly, it is possible that there has been a change in the extent and/or structure of the littoral habitat from climate warming and shoreline development, respectively. For example, climate warming could deepen the thermocline and, with an expanded epilimnion, favour chironomid taxa (at the expense of chaoborids) with higher VWHO optima that are more characteristic of littoral habitats. Shoreline development could cause disturbances in the benthic habitat and/or alter macrophyte growth, favouring chironomid taxa typically associated with the nearshore zone. This would effectively reduce the ratio of chaob:chir by increasing the relative abundance of subfossil chironomids independent of changes in hypolimnetic $\left[\mathrm{O}_{2}\right]$. Also, given that TP from residential development can be delayed in its impacts on aquatic systems (Robertson 1995), it is possible that the full effects of the recent surge in shoreline development on Poplar Bay may not yet be realized. Considering the multiple-stressor nature of Poplar Bay, it is plausible that other variables, such as increased availability of littoral habitats or a combination of multiple pressures, are driving the midge assemblage composition. Given the low midge counts ( $<50$ whole chironomids or Chaoborus equivalents) in the top three intervals of the Poplar Bay sedimentary core ( 2004 - 2007), interpretations of trends in this part may not be as robust compared to the rest of the core. The multiple stressors acting on Poplar Bay make it a complex system to interpret and the interactions between stressors may lead to ecological changes that are difficult to predict.
Based on a TP budget for LOW, Hargan (2010) suggests that if the present-day seasonal cottages built on the shorelines of Poplar Bay were to become permanent dwellings, [TP] in the bay would increase by $12.6 \mu \mathrm{g} \mathrm{L}^{-1}$, far exceeding estimates of [TP] increase due to doubling the number of cottages built on the bay $\left(5.1 \mu \mathrm{g} \mathrm{L}^{-1}\right)$. The possibility that the full impact of the mid-1990s surge in cottage development has not yet been realized, combined with the possibility of an increase in permanent residency, highlights that the impact of shoreline development on the overall water quality of Poplar Bay will continue to remain a point of concern. The counterintuitive trends in hypolimnetic $\left[\mathrm{O}_{2}\right]$ coincident with rapid shoreline development and the strong correlations between the chaob:chir index, VWHO model, midge PCA sample scores, and observed temperatures suggest that climate-induced changes are playing an increasingly important role in influencing hypolimnetic $\left[\mathrm{O}_{2}\right]$ dynamics in Poplar Bay. The effects of climate warming in combination with the impacts of other stressors, such as shoreline development, likely yield cumulative effects that are not the same as the impacts of each individual stressor alone. It is possible that our midge assemblage data are reflecting these compounding impacts, and as a result, presenting unexpected findings. When climate-mediated changes in stratification and icecover phenology substantially influence hypolimnetic $\left[\mathrm{O}_{2}\right]$ independent of lake productivity changes, the effects of climate warming on a multiple-stressor system may complicate the traditional paradigm of increased anthropogenic nutrient inputs resulting in declines in hypolimnetic oxygen. Through diatom-based inferences of water quality, Quinlan et al. (2008) showed the effects of climate warming ultimately driving changes in assemblages, regardless of changes in nutrient inputs. Similarly, recent climate warming in the LOW region may pose challenges to midge-based inferences of hypolimnetic $\left[\mathrm{O}_{2}\right]$. Despite substantial changes in anthropogenic influences on lake productivity and consequent oxygen conditions, climate change may be strongly influencing hypolimnetic $\left[\mathrm{O}_{2}\right]$. Regardless, climate warming is playing an increasingly important role in the water quality changes in Poplar Bay.

\section{CONCLUSIONS}

Midge-inferred changes in hypolimnetic $\left[\mathrm{O}_{2}\right]$, both qualitative and quantitative, suggest that the water quality in Poplar Bay has deteriorated over the last two centuries. Hydromanagement activities at the turn of the $20^{\text {th }} \mathrm{Cen}$ tury likely led to the initial decline in hypolimnetic $\left[\mathrm{O}_{2}\right]$ that was further exacerbated by climate warming and shoreline development over the last few decades. The midge-inferred hypolimnetic $\left[\mathrm{O}_{2}\right]$ trends complement diatom-inferred [TP] trends from the same sediment core (Hyatt 2010). These midge and diatom-based studies from Poplar Bay provide independent lines of paleoecological 
evidence across different trophic levels. Both biological proxies correlate closely with instrumental records and show the complex impacts of multiple stressors on historical water quality. Taken collectively, the changes in midge assemblage composition, the chaob:chir index, the VWHO model, and the complementary diatom-based [TP] trends provide strong evidence that overall water quality in Poplar Bay has declined since the early $20^{\text {th }}$ Century. The results of this midge-based study highlight the complexities inherent in multiple stressor systems. A paleolimnological approach using multiple independent lines of evidence is beneficial in gaining a more comprehensive understanding of the compounding relation-ships in complex systems, such as Poplar Bay, and helps lake managers understand the history of water quality in a lake, thereby guiding the establishment of future mitigation strategies.

\section{ACKNOWLEDGMENTS}

We thank Tom Mosindy and Gavin Olson from the Ministry of Natural Resources in Kenora and Anna DeSellas from the Ministry of the Environment in Dorset for field and logistical support. We thank Crystal Hyatt for providing a foundation of data for this study, Kathryn Hargan for sharing helpful insights, and two anonymous reviewers for their valuable comments. Financial support for this research was provided by the Natural Sciences and Engineering Research Council of Canada (NSERC) to John Smol, the Ontario Ministry of the Environment, Dorset, Ontario, and Queen's Student Work Experience Program (SWEP) to Jamie Summers.

\section{REFERENCES}

Aagaard K. 1986. The chironomid fauna of North Norwegian lakes, with a discussion on methods of community classification. Holarct. Ecol. 9: 1-12.

Appleby PG. 2001. Chronostratigraphic techniques in recent sediments. In: W.M. Last, and J.P. Smol (Eds), Tracking Environmental Change Using Lake Sediments. Vol. 1: Basin Analysis, Coring, and Chronological Techniques. Kluwer Academic Publishers, Dordrecht, Netherlands: 171-176.

Bazzanti M, Seminar M, Baldoni S, and Dowgiallo MG. 1998. Assessing hypolimnetic stress in a monomictic, eutrophic lake using profundal sediment and macrobenthic characteristics. J. Freshwater Ecol. 13: 405-412.

Blumberg AF, and Di Toro DM. 1990. Effects of climate warming on dissolved oxygen concentrations in Lake Erie. Trans. Am. Fish. Soc. 119: 210-223.

Brodersen KP, and Lindegaard C. 1999. Classification, assessment and trophic reconstruction of Danish lakes using chironomids. Freshwater Biol. 42: 143-157.

Brodersen KP, and Quinlan R. 2006. Midges as palaeoindicators of lake productivity, eutrophication and hypolimnetic oxygen. Quat. Sci. Rev. 25: 1995-2012.

Brooks SJ, Bennion H, and Birks JB. 2001. Tracing lake trophic history with a chironomid-total phosphorus inference model.
Freshwater Biol. 46: 513-533.

Brooks SJ, Langdon PG, and Heiri O. 2007. The Identification and Use of Palaearctic Chironomidae Larvae in Palaeoecology. QRA Technical Guide No. 10. Quaternary Research Association, London, UK: 276 pp.

Christensen MR, Graham MD, Vinebrooke DL, Paterson MJ, and Turner MA. 2006. Multiple anthropogenic stressors cause ecological surprises in boreal lakes. Glob. Change Biol. 12: 2316-2322.

Clerk S, Hall RI, and Smol JP. 2000. Quantitative inferences of past hypolimnetic anoxia and nutrient levels from a Canadian Precambrian Shield lake. J. Paleolimnol. 23: 319-336.

Clerk S, Selbie DT, and Smol JP. 2004. Cage aquaculture and water-quality changes in the LaCloche Channel, Lake Huron, Canada: a paleolimnological assessment. Can. J. Fish. Aquat. Sci. 61: 1691-1701.

Czeczuga B. 1960. Haemoglobin content of the larvae of Tendipes fl. plumous L. from various levels of bed sediment. Nature 186: 484.

DeSellas AM, Paterson AM, Clark BJ, Baratono NG, and Sellars TJ. 2009. State of the Basin Report for the Lake of the Woods and Rainy River Basin. Multiagency Technical Report http://www.lowwsf.com/index/php/progress-we-aremaking/state-of-the-basin-report.html: $133 \mathrm{pp}$.

Glew JR. 1988. A portable extruding device for close interval sectioning of unconsolidated core samples. J. Paleolimnol. 1: 235-239.

Glew JR. 1989. A new trigger mechanism for sediment samples. J. Paleoloimnol. 2: 241-243.

Grimm EC. 2004. TGView version 2.0.2. Illinois State Museum. Research and Collection Centre, Springfield, IL, USA.

Hall RI, and Smol JP. 2010. Diatoms as indicators of lake eutrophication. In: J.P. Smol, and E.F. Stoermer (Eds), The Diatoms: Applications for the Environmental and Earth Sciences, 2nd ed. Cambridge University Press, Cambridge, UK: 122-151.

Hargan K. 2010. A Total Phosphorus Budget for the Lake of the Woods. M.Sc. thesis, Trent University, Peterborough, ON, Canada: $152 \mathrm{pp}$.

Hargan KE, Paterson AM, and Dillon PJ. 2012. A total phosphorus budget for the Lake of the Woods and the Rainy River catchment. J. Great Lakes Res.: (in press).

Hyatt CV. 2010. A Diatom-based Paleolimnological Investigation of Historical Water Quality and Ecological Changes in the Lake of the Woods, Ontario. M.Sc. thesis, Queen's University, Kingston, ON, Canada: 423 pp.

Hyatt CV, Paterson AM, Rühland KM, and Smol JP. 2011. Examining 20th Century water quality and ecological changes in the Lake of the Woods, Ontario, Canada: a paleolimnological investigation. J. Great Lakes Res., 37: 456-469.

International Joint Commission (IJC). 1984. Briefing paper on International Rainy Lake Board of Control, International Lake of the Woods Control Board.

Jäger JS, and Walz N. 2002. Chaoborus flavicans (Diptera) is an oxyregulator. Arch. Hydrobiol. 155: 401-411.

Jankowski T, Livingstone DM, Bührer H, Forster R, and Niederhauser P. 2006. Consequences of the 2003 European heat wave for lake temperature profiles, thermal stability, and hypolimnetic oxygen depletion: implications for a warmer world. Limnol. Oceanogr. 51: 815-819. 
Juggins S. 2007. C2 Version 1.5 user guide. Software for ecological and palaecological data analysis and visualization. Newcastle University, Newcastle upon Tyne.

Kajak Z. 1997. Chironomus plumosus - what regulates its abundance in a shallow river? Hydrobiologia 342: 133-142.

Keller W. 2009. Limnology in northeastern Ontario: from acidification to multiple stressors. Can. J. Fish. Aquat. Sci. 66: 1189-1198.

Lake of the Woods Control Board (LOWCB). 2002. Managing the water resources of the Winnipeg River Drainage Basin, 2nd ed. http://www.lwcb.ca/permpdf/LWCB Brochure2002 Nov.pdf

Little JL, Hall RI, Quinlan R, and Smol JP. 2000. Past trophic status and hypolimnetic anoxia during eutrophication and remediation of Gravenhurst Bay, Ontario: comparison of diatoms, chironomids, and historical records. Can. J. Fish. Aquat. Sci. 57: 333-341.

Luoto TP and Salonen VP. 2010. Fossil midge larvae (Diptera: Chironomidae) as quantitative indicators of late-winter hypolimnetic oxygen in southern Finland: a calibration model, case studies and potentialities. Boreal Environ. Res. 15: 1-18.

McElroy RM, and Riggs T. 1943. The Unfortified Boundary: A Diary of the First Survey of the Canadian Boundary Line from St. Regis to the Lake of the Woods. Privately printed, New York, NY, USA.

Ontario Geological Survey. 2010. Ontario Ministry of Northern Development, Mines, and Forestry http:/www.mndm. gov.on.ca/mines/ogs/topics/Bedrock_geology e.asp.

Paerl HW, and Huisman J. 2008. Blooms like it hot. Science 320: 57-58.

Pla S, Paterson AM, Smol JP, Clark BK, and Ingram R. 2005. Spatial variability in water quality and surface sediment diatom assemblages in a complex lake basin: Lake of the Woods, Ontario, Canada. J. Great Lakes Res. 31: 253-266.

Quinlan R, and Smol JP. 2001a. Chironomid-based inference models for estimating end-of-summer hypolimnetic oxygen from south-central Ontario shield lakes. Freshwater Biol. 46: 1529-1551.

Quinlan R, and Smol JP. 2001b. Setting minimum head capsule abundance and taxa deletion criteria in chironomidbased inference models. J. Paleolimnol. 26: 327-342.

Quinlan R, Hall RI, Paterson AM, Cumming BF, and Smol JP. 2008. Long-term assessments of ecological effects of anthropogenic stressors on aquatic ecosystems from paleoecological analysis: challenges to perspectives of lake management. Can. J. Fish. Aquat. Sci. 65: 933-944.

Quinlan R, and Smol JP. 2010. Use of subfossil Chaoborus mandibles in models for inferring past hypolimnetic oxygen. J. Paleolimnol. 44: 43-50.

Ramcharan CW, Yan ND, McQueen DJ, Pérez-Fuentetaja A, Demers E, and Rusak JA. 2001. Complex responses of Chaoborus to changes in fish populations. Arch. Hydrobiol. Spec. Issues Advanc. Limnol. 56: 81-100.

Reavie ED, Neil KE, Little JL, and Smol JP. 2006. Cultural eutrophication trends in three southeastern Ontario lakes: a paleolimnological perspective. Lake Reserv. Manage. 22: 44-58.
Roberston H, and McCracken M. 2003. Magical, Mysterious Lake of the Woods. Heartland Associates, Winnipeg, MB, Canada: 252 pp.

Roberston WD. 1995. Development of steady-state phosphate concentrations in septic system plumes. J. Contam. Hydrol. 19: 289-305.

Rühland KM, Paterson AM, and Smol JP. 2008. Hemisphericscale patterns of climate-related shifts in planktonic diatoms from North American and European lakes. Glob. Change Biol. 14: 2740-2754.

Rühland KM, Paterson AM, Hargan K, Jenkin A, Clark BJ, and Smol JP. 2010. Reorganization of algal communities in the Lake of the Woods (Ontario, Canada) in response to turnof-the-century damming and recent warming. Limnol. Oceanogr. 55: 2433-2451.

Scholz F, and Zerbst-Boroffka I. 1998. Environmental hypoxia affects osmotic and ionic regulation in freshwater midgelarvae. J. Insect Physiol. 44: 427-436.

Serieyssol C, Edlund M, and Kallemeyn L. 2009. Impacts of settlement, damming, and hydromanagement in two boreal lakes: a comparative paleolimnological study. J. Paleolimnol. 42: 497-513.

Smol JP. 2008. Pollution of Lakes and Rivers: A Paleoenvironmental Perspective, 2nd ed. Wiley-Blackwell Publishing, Oxford, UK: 383 pp.

Smol JP. 2010. The power of the past: using sediments to track the effects of multiple stressors on lake ecosystems. Freshwater Biol. 55 (Supp. 1): 43-59.

Sweetman JN, and Smol JP. 2006. Reconstructing fish populations using Chaoborus (Diptera: Chaoboridae) remains - a review. Quat. Sci. Rev. 25: 2013-2023.

ter Braak CJF, and Šmilauer P. 2002. CANOCO Reference Manual and CanoDraw for Windows User's Guide: Software for Canonical Community Ordination, v. 4.5. Microcomputer Power, Ithaca, NY, USA.

Uutala AJ. 1990. Chaoborus (Diptera: Chaoboridae) mandiblespaleolimnological indicators of the historical status of fish populations in acid-sensitive lakes. J. Paleolimnol. 4: 139152.

Walker IR. 2001. Midges: Chironomidae and related Diptera. In: J.P. Smol, J.B. Birks, and W.M. Last (Eds), Tracking Environmental Change Using lake sediments. Vol. 4. Zoological Indicators. Kluwer Academic Publishers, Dordrecht, Netherlands: 43-66.

Weber RE. 1980. Functions of invertebrate hemoglobins with special reference to adaptations to environmental hypoxia. Am. Zool. 20: 79-101.

Wiederholm T. 1983. Chironomidae of the Holarctic region: Keys and Diagnoses Part 1- Larvae. Ent. Scand. Suppl. 19: $457 \mathrm{pp}$.

Wissel B, Yan ND, and Ramcharan CW. 2003. Predation and refugia: implication for Chaoborus abundance and species composition. Freshwater Biol. 48: 1421-1431.

Yang Z, and Teller J. 2005. Modeling the history of Lake of the Woods since 11,000 cal yr B.P. using GIS. J. Paleolimnol. 33: 483-498. 